\title{
ANALISIS KONTROVERSI VAKSIN COVID-19, MICROCHIP 666 DAN ANTIKRIS DI TENGAH GEREJA DI INDONESIA BERDASARKAN WAHYU 13:16-18
}

\section{Djone Georges Nicolas}

STT Ikat Jakarta - Pascasarjana

Email: djonealexandrenathanael@gmail.com

\begin{abstract}
The purpose of this study is to analyze and answer doubts over the doctrinal controversy that has recently been circulating among believers, regarding the Covid-19 vaccine which is linked to the microchip 666 and anti-Christ implantation revealed in the Book of Revelation 13: 16-18, thereby building a phobia in the middle. God's people. Can Christians be vaccinated against Covid-19? Is it true that the vaccine contains a 666 microchip? What if it is true that the Covid-19 vaccine contains the anti-Christ gene so that it is possible that the vaccine will perish? This study uses a qualitative approach with descriptive methods and literature analysis. First, the Covid-19 vaccine, even though it is controversial, is still a vaccine like other vaccines that have existed before, so it doesn't need to be connected to the 666 microchip and the antichrist. Second, even if the Covid-19 vaccine contains the anti-Christ gene, will this liquid invalidate our belief in Jesus Christ? The answer is clearly not at the same time rejecting the issue of perishing due to being vaccinated against Covid-19. Third, being vaccinated against covid-19 is a sign of obedience to the government as God's representative on earth, as well as an act of love, because it does not only protect ourselves, but also protect other people around us. The conclusion is that the refusal of the Covid-19 vaccine vaccination due to doctrinal reasons linking it to the 666 microchip and antiChrist, is an unfounded mistake. Being vigilant is good and must be for believers according to the advice of God's word, but the Covid-19 vaccine is not a threat to the salvation of believers as long as faith in Jesus Christ is not denied, because whatever the contents of the Covid-19 vaccine liquid cannot separate believers of God's love in Christ Jesus (Rom. 8: 35-39). Therefore, believers must set an example by faith in receiving the Covid-19 vaccine vaccination as recommended by the government.
\end{abstract}

Keywords: Controversy; Covid-19 Vaccine; Chip 666; Antichrist; Church in Indonesia.

\section{Abstrak}

Tujuan penelitian ini adalah menganalisa dan menjawab keraguan atas kontroversi doktrinal yang belakangan ini beredar di kalangan orang percaya, berkaitan vaksin Covid-19 yang dihubungkan dengan penanaman microchip 666 dan antiKris yang diwahyukan di dalam Kitab Wahyu 13:16-18, sehingga membangun fobia di tengah umat Allah. Apakah orang Kristen boleh divaksin covid-19? Apa benar vaksin tersebut mengandung microchip 666? Bagaimana kalau benar vaksin covid-19 
mengandung gen antiKristus sehingga kemungkinan yang divaksin akan binasa? Penelitian ini menggunakan pendekatan kualitif dengan metode deskriptif dan analisa literatur. Pertama, vaksin Covid-19 walaupun menjadi kontroversi tetaplah sebuah vaksin seperti vaksin lain yang sudah ada sebelumnya, sehingga tidak perlu dihubungkan dengan microchip 666 dan antikristus. Kedua, seandainya pun vaksin covid-19 mengandung gen antiKristus, apakah cairan tersebut membatalkan iman percaya kita kepada Yesus Kristus? Jawabannya jelas tidak sekaligus menolak isu binasa karena divaksinasi Covid-19. Ketiga, divaksin covid-19 merupakan tanda ketaatan pada pemerintah sebagai wakil Allah di bumi, sekaligus tindakan kasih, sebab dengan demikian bukan sekedar melindungi diri, tetapi juga melindungi orang lain di sekitar kita. Kesimpulannya adalah bahwa penolakan vaksinasi vaksin Covid-19 karena alasan doktrinal yang mengkaitkannya dengan microchip 666 dan antiKristus, merupakan suatu kekeliruan yang tidak berdasar. Berjaga-jagalah adalah baik dan harus bagi orang-orang percaya sesuai anjuran firman Tuhan, tetapi vaksin Covid-19 bukanlah suatu ancaman bagi keselamatan orang percaya selama iman kepada Yesus Kristus tidak sangkali, sebab apapun isi cairan vaksin Covid-19 tidak dapat memisahakan orang percaya dari kasih Allah di dalam Kristus Yesus (Rom.8:35-39). Oleh karena itu, orang-orang percaya harus memberi teladan dengan penuh iman menerima vaksinasi vaksin Covid-19 sesuai anjuran pemerintah.

Kata Kunci: Kontroversi; Vaksin Covid-19; Chip 666; Antikris; Gereja di Indonesia.

Coresponden Author

Email: djonealexandrenathanael@gmail.com Artikel dengan akses terbuka dibawah lisensi

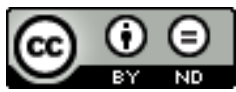

\section{Pendahuluan}

Sejak awal kemunculan Coronavirus desease yang lebih dikenal di Indonesia dengan istilah Covid-19 yang pada akhirnya ditetapkan oleh Organisasi Kesehatan Dunia (WHO) sebagai pandemi, bermunculan pula berbagai teori yang menjadi kontroversial di kalangan orang percaya.

Joshua Boyke Tewuh dalam refleksi pastoral-nya di situs Youtube Henry E.P. Manalu mengaitkan Covid-19 dengan strategi konspirasi sekte illuminati yang dikepalai oleh sang Dajjal atau antiKris dalam rangka mengiring semua orang untuk menerima implantasi microchip 666 melalui imunisasi dengan alasan sebagai solusi ampuh melawan Covid-19 sehingga menjadi pengenapan nunuatan Alkitab yang ditulis di Kitab Wahyu 13:16-18. Ada pula yang menyatakan bahwa virus corona sesungguhnya bukanlah virus alami, tetapi sebaliknya merupakan buatan para pemuja setan dengan tujuan membawa kekacauan di tengah dunia, dikarenakan Covid-19 adalah representasi dari simbol 666 (Christina, 2020). Sebagian lain mengaitkan Covid-19 dengan tentara Allah dengan tujuan menghancurkan musuh-musuhNya (Sabara, 2020). Menurut Henry Makow, sejarah tidak bersifat aksidental, tetapi merupakan hasil dari konspirasi jangka panjang satanis agar derajat manusia menurun sehingga dapat diperbudak melalui 
kebohongan mereka, dalam hal ini sekte Illuminati (Makmun \& Hazhiyah, 2020). Namun bagi para Pejabatan Majelis Daerah Gereja Bethel Injil Sepenuh (GBIS) Jawa Tengah, 98,1\% meyakini bahwa penyebab Covid-19 bukanlah hal lain tetapi sematamata karena virus (Setiawan, Purwoto, \& Stevanus, 2020).

Setelah penantian lama vaksin di tengah pandemi Covid-19 yang masih belum usai, akhirnya Presiden Negara Kesatuan Republik Indonesia Joko Widodo menjadi pribadi yang pertama menerima vaksinasi vaksin Covid-19 sebagai tindakan memberi motivasi dan dorongan kepada rakyat untuk tidak meragukan dan tidak menolak vaksinasi tersebut menurut berita CNBC Indonesia. Namun, kontroversi berkaitkan vaksin Covid-19 munculan juga. Anggota Dewan Perwakilan Rakyat (DPR) Ribka Tjiptaning dengan terang-terangan menolak divaksinasi vaksin Covid-19 dan lebih memilih membayar denda dengan alasan vaksin tersebut belum uji klinis ketiga menurut berita Liputan 6 pada 12 Januari 2021 sehingga mengakibatkan pro dan kontra di tengah masyarakat. Menurut Muh Alim Masnun, vaksin Covid-19 merupakan pemenuhan tanggung jawab pemerintah sebagaimana diatur undang-undang NRI Tahun 1945 (Masnun, Sulistyowati, \& Ronaboyd, 2021). Ada yang mengaku Tuhan berbicara dan memesan langsung dalam doa bahwa harus menolak vaksinasi vaksin Covid-19, dikarenakan di dalamnya terkandung "gen antiKristus" sehingga ditanggapi oleh Pdt Esra Alfred Soru pada 16 Januari 2021 dalam situs Youtube pribadinya dengan menyatakan telah muncul fenomena dua golongan, yakni golongan eskatofobia atau orang yang takut berbicara tentang hal apapun yang berkaitan dengan akhir zaman, dan golongan eskatomania atau orang yang hobynya mengaitkan segala sesuatu dan fenomena dengan akhir zaman. Dalam Youtube Rubin Adi Abraham TV tanggal 2 Januari 2021, Pdt. Rubin Adi Abraham sebagai Ketua Umum Gereja Bethel Indonesia di situs Youtube pribadinya, menyatakan bahwa orang Kristen boleh divaksin Covid-19 dikarenakan berfungsi sebagai perlindungan agar tubuh lebih sehat melalui hikmat yang Tuhan beri kepada manusia, dalam hal ini para peneliti dan para dokter. Apakah orang Kristen boleh divaksin covid-19? Apa benar vaksin tersebut mengandung microchip 666? Bagaimana kalau benar vaksin covid-19 mengandung gen antiKristus apakah kita akan binasa? Itulah sejumlah pertanyaan jemaat yang akan dijawab sehingga dapat menerangi pemahaman orang-orang percaya seturut dengan kebenaran Alkitab yang merupakan satu-satunya kebenaran bagi orang Kristen.

Secara fakta sedikit maupun banyak, kontroversi yang beredar dan menghebohkan di mimbar-mimbar gereja online tentang fenomena yang mengkaitkan antara Covid-19, vaksin Covid-19, microchip 666 dan antiKris sudah memberi pengaruh negatif pada cara pandang sebagian orang percaya dalam meresponi pandemi Covid-19 yang terus berlangsung hingga saat ini, sehingga hal tersebut apabila tidak diluruskan dapat merugikan pribadi lepas pribadi, maupun organisasi seperti gereja dan pemerintah yang sedang berusaha dengan keras mengatasi masalah pandemi yang semakin memakan korban setiap hari. Sebab, apabila tidak berhikmat gereja justru dapat menjadi alat yang digunakan Iblis dalam menyebarkan ketakutan melalui penyesatan dan hoax. Oleh karenanya, penulis mempunyai dorongan untuk menganalisa dan menjawab keraguan 
atas kontroversi doktrinal yang belakangan ini beredar di kalangan orang percaya, berkaitan vaksin Covid-19 yang dihubungkan seperti di jabarkan di Youtube oleh Pdt. Wignyo Tanto pada tanggal 7 Januari lalu di Youtube (Thruth.id) dengan penanaman microchip 666 dan antiKris yang di dalam Kitab Wahyu 13:16-18.

\section{Metode Penelitian}

Penelitian ini menggunakan pendekatan kualitif dengan metode deskriptif dan analisa literatur maupun literatur research dengan tujuan menganalisa dan menjawab keraguan atas kontroversi doktrinal yang belakangan ini beredar di kalangan orang percaya, berkaitan vaksin Covid-19 yang dihubungkan dengan penanaman microchip 666 dan antiKris yang diwahyukan di dalam Kitab Wahyu 13:16-18. Untuk mencapai tujuan tersebut, teknik pengumpulan data melalui Alkitab, sumber buku-buku, artikel digital, jurna-jurnal, wawancara serta dokumen lain yang berkaitan dengan masalah yang menjadi objek kajian. Penelitian kualitatif menurut (Bogdan \& Biklen, 1997) merupakan prosedur penelitian yang menghasilkan tipe data deskriptif yang berupa ucapan atau tulisan dan perilaku orang-orang yang diamati di dalam suatu konteks dan yang dikaji dari sudut pandang yang lengkap dan komprehensif, maupun menyeluruh atau holistik. Deskriptif karena mempelajari masalah-masalah di tengah masyarakat serta pengaruh-pengaruh dari suatu fenomena. Analisa data dilakukan penulis dengan menggunakan metode hermeneutika untuk menggali makna yang benar berdasarkan teks Kitab Wahyu 13:1618, kemudian berdasarkan analisis teks dan historisnya, mencoba menghubungkannya dengan persoalan fenomena kontroversi doktrinal yang terus beredar di tengah krisis pandemi Covid-19 agar menjadi sebuah uraian yang mendalam.

\section{Hasil dan Pembahasan}

\section{A. Genre Wahyu 13:16-18}

Kitab Wahyu dipandang sebagai salah satu Kitab yang tersulit untuk dipahami dalam Alkitab, oleh karena isinya dipenuhi simbol-simbol yang mungkin membinggungkan para pembacanya. Kitab Wahyu merupakan kita dengan genre sastra Apokaliptik atau mengenai akhir zaman. Dalam bahasa Indonesia "Wahyu" berasal dari kata Yunani "apokaluqiv" yang mempunyai makna dalam bahasa Inggris sebagai "revelation, disclousure, manifestation" yang kalau diterjemahkan dalam bahasa Indonesia mempunyai makna "membuka, menyatakan, menyingkapkan. Wahyu 1:1 memberi gambaran yang jelas tentang genrenya dengan diawali pernyataan "Inilah Wahyu Yesus Kristus...", sehingga atas dasar tersebut Kitab Wahyu merupakan buku yang berisi penyingkapan tentang nubuatan akhir zaman tentang rahasia ilahi (Wahyu. 1:3; 22:7, 10, 18-19).

Berdasarkan pernyataan (McAllister, 2020), gematria merupakan salah satu cara dari empat cara yang ada dalam penggunaan angka. Gemetaria berdasarkan situs kompasiona.com merupakan suatu ilmu numerologi yang dipakai dalam rangka mendapatkan makna yang tersembunyi di balik tulisan dengan cara menghitung nilai numerik dari setiap huruf. Penafsiran Kitab Wahyu 13:16 tentang 
angka bilangan 666 menjadi perhatian khusus bagi hampir semua orang percaya, oleh karena disebut angka gaib terhubung dengan. antiKristus, sehingga Yuresti dengan mengutip Donald C. stamps menulis empat golongan penafsiran yang lahir dari bermacam-macam pandangan mengenai makna Kitab wahyu: yakni, penafsiran preterist yang mengkaitkan peristiwa ini dengan masa lampau, kemudian penafsiran historistic yang jelas memberi tekanan pada unsur sejarah, lalu penafsiran idealistik yang memberi tekanan pada pikiran yang ideal, dan yang terakhir penafsiran futurist yang berbicara masa yang akan datang (To'Bungan Yuresti, 2016).

\section{B. Vaksinasi Vaksin Covid-19: Halal atau Haram}

Berdasarkan hasil proses wawancara dengan tiga narasumber pada tanggal 16 Januari 2021, Desi Ayu pandemi menyatakan: "Vaksin Covid-19 itu mencurigakan, soalnya kelihatan dipaksakan oleh pemerintah sampai memberi denda sebesar 5 Juta Rupiah bagi yang menolak divaksin. Ada apa di balik vaksin ini. Saya tidak akan mau divaksin". Menurut Ferdinand Silalahi, "virus corona merupakan konspirasi buatan masusia dan vaksin Covid-19 adalah sarana untuk ditanamkan chip. Antikris sudah di depan mata, tetap banyak orang tidak menyadarinya". Berbeda pendapat Evangelist Alfons Abednego menyatakan bahwa sama seperti penyakit yang lain, dampak Covid-19 nyata dengan fakta banyak kematian, sehingga vaksin menjadi kebutuhan dan tidak usah ditafsirkan dengan tanda 666.

Vaksin Covid-19 merupakan langkah medis atas rekomendasi WHO yang adalah Organisasi Kesehatan Dunia dalam rangka mengatasi pandemi yang terus menerus memakan korban nyawa. Dalam dunia medis, berbagai vaksin telah terbukti efektif dalam penangganan pandemi sebelumnya seperti cacar, tuberkulosis (TBC) maupun polio dan sebagainya. Menurut Armanto Makmun dan Siti Fadhila Hazhiyah (2020), vaksin merupakan cara paling ampuh dan ekonomis mencegah penyakit yang dapat menular termasuk Covid-19, sehingga vaksin Covid-19 sangat diperlukan. Maka mengacu pada Undang-Undang Nomor 6 Tahun 2018 tentang Kekarantinaan Kesehatan, berdasarkan berita voa.indonesia.com terbitan tanggal 19 Januari 2021, Wakil Menteri Hukum dan Hak Asasi Manusia Profesor Edward Omar Syarif Hariej senada Menteri Koordinator Bidang Politik, Hukum dan Keamanan Profesor Mahfud MD menyampaikan bahwa vaksinasi Covid-19 adalah kewajiban seluruh rakyat Indonesia demi kepentingan bersama. Oleh karena yang tidak divaksin mengancam hak kesehatan orang lain.

Gereja hadir untuk memberitakan shalom bagi dunia ini melalui Kabar Baik, dan bukan sebaliknya menghadirkan ketakutan dan kebimbangan. Oleh karena itu, orang percaya bukan sekedar boleh divaksinasi, tetapi harus bersedia divaksinasi vaksin Covid-19 sesuai anjuran pemerintah sebagai bentuk ketaatan dan kepedulian, sebab orang-orang percaya dipanggil untuk menjadi teladan dalam situasi dan kondisi apapun dan dimana pun. 


\section{Pandemi Covid-19, Vaksin Covid-19 tidak perlu dihubungkan dengan Microchip 666 dan AntiKristus}

\section{Analisis Wahyu 13:16-18}

“... diberi tanda pada tangan kanannya atau pada dahinya" (Wahyu 13:16).

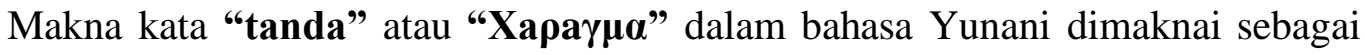
stempel (a stamp), tanda yang dicetak (an imprinted mark) seperti tanda merek yang dicap di atas tubuh (the mark branded upon horses) atau gambar pemuja berhala (idolatrus images). Dengan kata lain, apabila ditafsirkan secara harfiah tanda tersebut merupakan tanda yang nampak dan harus bisa dilihat dan diteguhkan di ayat 17 yang menyatakan tidak ada yang dapat bertransaksi tanpa tanda nama atau bilangan nama binatang tersebut. Berdasarkan fakta tersebut, dapat diambil kesimpulan bahwa tidak terdapat hubungan antara vaksin Covid19 dan tanda microchip 666 maupun antiKristus, oleh karena cairan vaksin justru dimasukkan di dalam tubuh manusia sehingga seandainya dikaitkan dengan microchip 666, tidak memenuhi kriteria tanda yang terdapat di Kitab Wahyu 13:16-18 yang harus dapat dilihat dan angka 666 bukan sekedar tanda antiKristus, tetapi sekaligus merupakan nama dan bilangan antiKristus sebagai manusia. Fakta di atas menolak pendapat Jopie Rattu dkk yang menyatakan mempunyai keyakinan yang kuat bahwa tanda angka 666 merupakan barcode (Rattu Jopie, Sridadi Atiyanto, 2013).

Apabila dibandingkan dengan Kitab Ulangan 6:8 "Haruslah engkau mengikatkannya sebagai tanda pada tanganmu dan haruslah itu menjadi lambang pada dahimu" yang berkaitan perintah kepada orang Israel untuk mengajarkan turun temerun kepada anak-anak mereka bahwa hanya Dia lah Satu-satunya Tuhan dan tidak ada yang, tentunya tanda sini tidak dapat diartikan secara harfiah. Demikian juga, dikarenakan Kitab Wahyu bergenre apokaliptik, tanda 666 tidak dapat diartikan secara harfiah sebagai berhubungan dengan simbol. Sebagai salah satu contoh, Ferdinan S. Manafe berpendapat bahwa apabila dikaitkan dengan ibadah, kitab Wahyu 13 tidak berhubungan dengan Iblis atau Antikristus walaupun sempat disinggung penyembahan terhadap naga dan sang binatang di Wahyu 13:4-12, tetapi sepenuhnya kitab Wahyu menunjukkan ibadah yang terfokus kepada Allah Tritunggal sebagai model ibadah Perjanjian Baru (Ferdinan, 2012).

Wahyu 13:13 diawali dengan sebuah catatan penting: "Yang penting disini ialah hikmat: barangsiapa yang bijaksana, baiklah ia menghitung bilangan binatang itu...". Jelas penekanan diberi pada "hikmat" atau "бoфía" dalam Yunani dan "wisdom" dalam bahasa Inggris yang bukan berbicara hikmat dari dunia ini, melainkan hikmat dari tempat yang Maha Tinggi. Yang artinya tidak boleh diartikan sesuai pikiran dan kehendak sendiri. Maka, catatan selanjutnya adalah kata "kebijaksanaa" atau "voũ $\varsigma$ " dalam bahasa Yunani dan "understanding" dalam bahasa Inggris dan mempunyai makna pengertian atau arti yang dalam dari. Tentunya hanya hikmat yang dari Allah yang dapat memberi memberi 
pengertian atas rahasia atau arti yang tersembunyi di balik nubuatan yang Allah sampaikan. Mark Hitchcok dalam bukunya berjudul "Who is The AntiChrist?" menyampaikan bahwa salah satu dari 10 kunci memahami tanda angka 666 sebagai tanda binatang adalah bahwa tanda tersebut bersifat lahiriah seperti cap yang kasat mata maupun seperti tatoo (Mark, 2016).

Maka, Imanuel Sukardi berpendapat bahwa bagian tersulit dari doktrin gereja adalah kesulitan hilangkan kesalah pahaman serta citra mental buruk yang sudah terlanjur melanda gereja, sehingga diperlukan pembersihan pikiran dengan mengizinkan Alkitab dan Roh Kudus menafsirkannya (Y.M. Imanuel Sukardi, 2018).

Kata penting berikutnya adalah "menghitung" atau " $\psi \eta \varphi 1 \zeta \omega "$ (psephizo) dalam bahasa Yunani yang dimaknai seperti menggunakan kerikil dalam pencacahan. Dengan kata lain, menghitung dengan teliti atau dengan hati-hati, bukan asal mengkaitan fenomena alam seperti Covid-19 maupun vaksin Covid19 yang adalah vaksin seperti vaksin yang lain. Menurut Daud Darmadi justru debat tentang topik antikristus sebatas apakah dia adalah pribadi atau tokoh di bidang politik, atau mungkin lembaga religious tertentu. Namun, yang pasti pribadi anti Kristus tidak hanya menjadi lawan Kristus, tetapi di sisi lain usahanya adalah untuk mengambil alih posisi Kristus sebagai penguasa (Daud, 2019).

Penolakan vaksinasi vaksin Covid-19 karena alasan doktrinal yang mengkaitkannya dengan microchip 666 dan antiKristus, merupakan suatu kekeliruan yang tidak berdasar, oleh karena menurut Wahyu 13:16-18 tanda yang diterima berupa tanda yang nampak seperti stempel di tangan kanan dan dahi, bukan ditanamkan di dalam tubuh. Oleh karena itu, orang-orang percaya harus memberi teladan dengan penuh iman menerima vaksinasi vaksin Covid-19 sesuai anjuran pemerintah.

\section{Kesimpulan}

Penolakan vaksinasi vaksin Covid-19 karena alasan doktrinal yang mengkaitkannya dengan microchip 666 dan antiKristus, merupakan suatu kekeliruan yang tidak berdasar. Berjaga-jagalah adalah baik dan harus bagi orang-orang percaya sesuai anjuran firman Tuhan, tetapi vaksin Covid-19 bukanlah suatu ancaman bagi keselamatan orang percaya selama iman kepada Yesus Kristus tidak sangkali, sebab apapun isi cairan vaksin Covid-19 tidak dapat memisahakan orang percaya dari kasih Allah di dalam Kristus Yesus (Rom.8:35-39). Oleh karena itu, orang-orang percaya harus memberi teladan dengan penuh iman menerima vaksinasi vaksin Covid-19 sesuai anjuran pemerintah, sebab gereja dipanggil dan diutus dengan tujuan menjadi terang dan garam dunia di dalam kondisi seburuk dan segelap apapun. Maka, vaksinasi vaksin Covid-19 menjadi suatu momentum bagi umat Tuhan untuk menunjukkan kasih melalui respon dan tindakan yang nyata dan penuh tanggung jawab, apa bila tidak ingin kasih yang dikenal sebagai ciri khas orang Kristen hanya menjadi slogan semata. 


\section{BIBLIOGRAFI}

Bogdan, Robert, \& Biklen, Sari Knopp. (1997). Qualitative research for education. United States: Allyn \& Bacon Boston, MA

Christina, Endah. (2020). Pandemi Covid-19 Adalah 666? Logia: Jurnal Teologi Pentakosta, 1(2), 1-22.

Darmadi Daud, 2019, Memahami Teologi Yohanes Tentang Akhir Zaman, KALUTEROS: Jurnal Teologi dan Pendidikan Kristen Vol. 1, No.1, 21-33.

Imanuel Y.M. sukardi, 2018. Gereja Ekstra Biblika dan Implikasinya Terhadap Penyelesaian Amanat Agung, Prudentia: Jurnal teologi dan Pendidikan Kristiani Vol. 1, No.1, 43-58.

Hitchcock Mark, 2016. Who is The AntiChrist? .Cet. 5, 104. Yogyakarta: Andi.

Makow Henry, 2015. Illuminati 2, PT Ufuk Publishing House, hlm. 22-28.Terkait

Pengembangan Vaksin Covid-19, Molucca Medica Vol. 13, No.2, 52-59.

Makmun, Armanto, \& Hazhiyah, Siti Fadhilah. (2020). Tinjauan Terkait Pengembangan Vaksin COVID 19. Molucca Medica, 52-59.

Manafe S. Ferdinan, 2012, Ibadah Perjanjian Baru Suatu Uraian Deskriptif Tentang Ibadah dan Kontribusinya bagi Ibadah Masa Kini, Missio Ecclesiae 1(1), 87-102.

Masnun, Muh Ali, Sulistyowati, Eny, \& Ronaboyd, Irfa. (2021). Pelindungan Hukum Atas Vaksin Covid-19 Dan Tanggung Jawab Negara Pemenuhan Vaksin Dalam Mewujudukan Negara Kesejahteraan. DiH: Jurnal Ilmu Hukum, 17(1).

McAllister, Colin. (2020). The Cambridge companion to apocalyptic literature. Cambridge: University Press.

Rattu Jopie, Sridadi Atiyanto, Yunus Ciptawilangga. (2013). Benarkah Chip Sebagai Penggenap 666?, Bandung: Terang Hidup, 4.

Sabara, Sabara. (2020). Beragama Dengan Moderat di Era Pandemi Covid-19. Mimikri, $6(2), 131-149$.

Setiawan, David, Purwoto, Purwoto, \& Stevanus, Kalis. (2020). Gambaran Persepsi Pejabat Gereja Bethel Injil Sepenuh (GBIS) Majelis Daerah Jawa Tengah tentang Pandemi Covid-19 dan Implikasinya bagi Pelayanan Gerejawi. Kharisma: Jurnal Ilmiah Teologi, 1(2), 89-116.

To'Bungan Yuresti. (2016). “Kajian Biblika Tentang Bilangan Binatang 666 berdasarkan Wahyu 13:11-18 dan Relevansinya Dalam Kehidupan Orang Percaya Masa Kini”, Skripsi, S. Th, Sekolah Tinggi Theologia Jaffray Makassar. 